\title{
Mimosine Increases the Expressions of Tyrosine Phosphorylated Protein in Mouse Seminal Vesicles
}

\author{
La Mimosina Aumenta la Expresión de la Proteína Tirosina \\ Fosforilada en las Vesículas Seminales del Ratón
}

\begin{abstract}
Amnart Chaichun'; Jaturon Burawat ${ }^{1}$; Supatcharee Arun ${ }^{1}$; Saranya Tongpan ${ }^{1}$; Pipatpong Kanla ${ }^{1}$; Tarinee Sawatpanich ${ }^{1} \&$ Sitthichai Iamsaard $^{1,2}$
\end{abstract}

Chaichun, A.; BURAWAT, J.; ARUN, S.; TONGPAN, S.; KANLA, P.; SAWATPANICH, T. \& IAMSAARD, S. Mimosine increases the expressions of tyrosine phosphorylated protein in mouse seminal vesicles. Int. J. Morphol., 37(4):1463-1468, 2019.

SUMMARY: Acute effect of purified mimosine (MiMo) extracted from Leucaena leucocephala on testicular histopathology has been documented with seminal vesicle (SV) atrophy. Since protein phosphorylation and seminal secretions play important roles in sperm physiology, this study aimed to study the alteration of substances including tyrosine phosphorylated (TyrPho) proteins in seminal vesicle treated with MiMo. Male mice were divided into a control and experimental groups treated with purified MiMo at 3 doses of 15, 30, and $60 \mathrm{mg} / \mathrm{KgBW}$, respectively for 35 consecutive days. The morphology and weights of SV were compared among groups. The levels of magnesium and fructosamine in SV fluid were assayed. The profiles of equally SV total proteins were compared using SDS-PAGE. The expression of seminal TyrPho proteins was detected by western blotting. Recent results showed the decreased weights of SV in MiMo treated mice compared to control. However MiMo in all doses did not affect the levels of magnesium and fructosamine in SV fluid. The SV protein expression of 130 and 55 kDas was obviously decreased in a high dose MiMo. In dose-dependent response, the expressions of 72 and $55 \mathrm{kDas}$ TyrPho proteins of SV were increased. In conclusion, MiMo could affect SV morphological size and protein secretions especially TyrPho proteins.

KEY WORDS: Mimosine (MiMo); Seminal vesicle; Tyrosine phosphorylated (TyrPho) protein; Mice.

\section{INTRODUCTION}

Mimosine (MiMo), a major component of Leucaena leucocephala (Lamk.) de Wit (LL), has been demonstrated to have inhibitory property of many cancers, cell divisions, and cell proliferations (Adeneye, 1991; Hughes \& Cook, 1996; Krude, 1999; Kubota et al., 2014). Additionally, previous studies showed that MiMo has the herbicidal, insecticide, and nematicide activities (Tawata, 1990; Nguyen \& Tawata, 2015). Such activities could be explained that MiMo has ability to arrest the cell cycle progression to inhibit cell proliferation and differentiation (Chung et al., 2012; Park et al., 2012; Bottini-Luzardo et al., 2015; Fallon, 2015; Nguyen \& Tawata). Therefore, LL plant containing MiMo has been reported to be toxic to cattle and poultry animals in growth retardation, sub or infertility, and morbidity (Wayman et al., 1970; Hammond, 1995; Anderson et al., 2001). Indeed, Burawat et al. (2016) have reported the presence of MiMo in crude LL leave extract and demonstrated its adverse effects on male reproductive organs including seminal vesicle (SV). Moreover, a previous study reported that acute treatment with purified MiMo for 7 consecutive days affected testicular, epididymal, and SV morphologies with significant reduction of sperm count (Kanla et al., 2018). Such results suggested that MiMo could directly inhibit spermatogenesis and testosterone production. It is known that male infertility is associated with SV secretion impairments especially magnesium and fructosamine deficiencies (Abou-Shakra et al., 1989; Tomaszewski et al., 1992; Omu et al., 2001; Wong et al., 2001). Although atrophy of SV treated with MiMo was observed (Burawat et al., 2016; Kanla et al.), its function such as electrolyte and protein secretion has never been reported. Essential secretions of SV may include various functional proteins including tyrosine phosphorylated (TyrPho) proteins (Camargo et al., 2018; Druart \& de Graaf, 2018). Particularly, TyrPho proteins have been localized in testicular and epididymal tissues (Chaichun et al., 2017; Sawatpanich et al., 2018) but in SV have never been reported. Moreover, TyrPho proteins have been reviewed to play

\footnotetext{
${ }^{1}$ Department of Anatomy, Faculty of Medicine, Khon Kaen University, Khon Kaen, 40002, Thailand.

${ }^{2}$ Research Institute for Human High Performance and Health Promotion (HHP \& HP), Khon Kaen University, Khon Kaen, 40002, Thailand.
} 
important roles in sperm capacitation and acrosome reaction (Seshagiri et al., 2007; Ickowicz et al., 2012). Taken together, this study attempted to investigate the effects of purified mimosine on secretion of seminal vesicle in male mice.

\section{MATERIAL AND METHOD}

Mimosine preparation. Purified L-Mimosine powders were purchased from Sigma-Aldrich, Lot\# 077K7007V, USA. The mimosine powder $(1 \mathrm{~g})$ was mixed with $0.1 \mathrm{~N} \mathrm{HCl}(\mathrm{pH} 7)$ to prepare stock solution.

Animals and treatments. ICR male mice ( 8 weeks) were purchased from the Animal Laboratory Unit, Faculty of Medicine, Khon Kaen University, Thailand. Animals were housed in plastic cages under a $12 \mathrm{~h}$ light/dark cycle at room temperature. This study was approved by the Animal Ethics Committee of KKU, based on the Ethics of Animal Experimentation of the National Research Council of Thailand (ref. No.0514.1.12.2/93). All mice were divided into 4 groups $(n=8)$; in control group, mice were i.p. injected with $0.1 \mathrm{~N} \mathrm{HCl}$ while experimental groups (mimosine 15, 30, and 60), animals were injected (i.p.) with mimosine at 15,30 , and $60 \mathrm{mg} / \mathrm{KgBW}$, for 35 consecutive days. At the end of experiment, all mice were euthanized and sacrificed to collect seminal vesicles.

Seminal weight analysis and gross morphology. The seminal vesicles (SV) from control and minosine treatedanimals were collected. The fat pads surrounding SV were gentle removed before weighing as absolute organ weight. Then, SVs were calculated as individual relative organ weights using a formulation of one hundred multiplied by the absolute weight of SV and divided by body weight ( $\mathrm{g}$ of $\mathrm{SV} / 100 \mathrm{gBw}$ ). After weighing the SV, the representative SV of control and mimosine treated groups were grossly observed for their sizes and morphology before captured by digital camera (Nikon Coolpix S2600, Japan).

Assay of magnesium and fructosamine levels in seminal fluid. To prepare seminal fluid, the fresh seminal vesicle was punctured using a micropipette tip and transferred into an eppendorf tube. Then, PBS was added into the seminal fluid and sonicated by ultrasonic homogenizer on ice. Subsequently, the diluted seminal fluid was centrifuged at $15,000 \mathrm{rpm}$ for $15 \mathrm{~min}$ at $4{ }^{\circ} \mathrm{C}$ to separate the seminal supernatant fluid from the pellet. The magnesium and fructosamine levels in seminal supernatant were measured using the colorimetric method. Phosphorus was measured with molybdate UV. PSA was measured by electrochemiluminescence immunoassay (ECLIA).
Western blot. Total protein concentration of seminal vesicle lysate was measured by using NanoDrop 2000 Spectrophotometers (Thermo Scientific) at an absorbance of $280 \mathrm{~nm}$. Eighty micrograms of seminal vesicle lysate was separated on a $12 \%$ acrylamide gel by sodium dodecyl-sulfate polyacrylamide gel electrophoresis (SDSPAGE) and transferred onto nitrocellulose membranes (BioRad, Hercules, CA, USA). The transferred protein membrane was incubated with $3 \%$ skim milk in 0.1 PBST (phosphate buffer solution, $\mathrm{pH} 7.4,0.1 \%$ [v/v] Tween 20) for $1 \mathrm{hr}$. Then, the seminal membranes were incubated with antiphosphotyrosine $\left(1: 1,000(\mathrm{v} / \mathrm{v})\right.$; Millipore Sigma) at $4{ }^{\circ} \mathrm{C}$ overnight. After washing the non-binding primary antibody with $0.05 \%$ PBST, the membranes were incubated with HRP-conjugated secondary antibody (goat anti-mouse IgG, Santa Cruz) at $25^{\circ} \mathrm{C}$ for $1 \mathrm{~h}$ and washed with $0.05 \%$ PBST for $5 \mathrm{~min}$ (three times). The positive protein expressions on the membrane were detected by enhanced chemiluminescence (ECL) substrate reagent kits (GE Healthcare, Chicago, Il, USA) under an Amersham Imager 600 (GE Healthcare). To confirm the real reactivity of anti TyrPho antibody, the epidermal growth factor stimulated A413 cell lysate (EGF; Millipore CO., USA) and bovine serum albumin (BSA; Millipore CO., USA) were used as positive and negative controls, respectively.

Statistical analysis. All data are expressed as mean \pm standard deviation (S.D.). The one way analysis of variance (ANOVA) was performed to examine the significant differences among sets of data using SPSS statistics 19.0 software. $\mathrm{P}<0.05$ was considered for significant difference.

\section{RESULTS}

Effect of mimosine on weight of seminal vesicle (SV). After injection with purified mimosine for 35 consecutive days, the results showed that the absolute weights of mouse SV treated with mimosine $(15,30$, or $60 \mathrm{mg} / \mathrm{KgBw})$ were significantly decreased in dose dependent manner from that of control mice (Fig. 1A, left panel). However, the SV relative weights in only 30 and $60 \mathrm{mg} / \mathrm{KgBw}$ groups were significantly decreased as compared to the control (Fig. 1A, right panel). This result is corroborated with its representative morphology as shown in Figure 1B.

Magnesium and fructosamine levels in SV fluid. The results showed that the magnesium and fructosamine levels in SV fluid in mimosine treated mice in 3 different doses were not significantly different when compared to the control (Figs. 2 A,B) 
Effects of mimosine (MiMo) on SV tyrosine phosphorylated (TyrPho) protein expression. The total protein profiles revealed by SDS-PAGE and expression of TyrPho proteins detected by western blot of SV protein lysate compared among control and MiMo treated groups were shown in Figure 3. The result showed that the protein profiles of all groups were relatively similar (Fig. 3A). However, it was obviously found that only a $130 \mathrm{kDa}$ protein in SV lysate of the high-dose MiMo group (60 $\mathrm{mg} / \mathrm{KgBw}$ ) was undetectable as compared to the rest groups (Fig. 3A). Moreover, the 72 and $55 \mathrm{kDas}$ TyrPho proteins were expressed in control and MiMo- treated seminal vesicles (Fig. 3B). Obviously, the expression of such TyrPho proteins in SV lysate were increased with dose dependent manner treated with purified MiMo $(15,30$, and $60 \mathrm{mg} / \mathrm{KgBw}$, respectively) as demonstrated in Figure 3B.
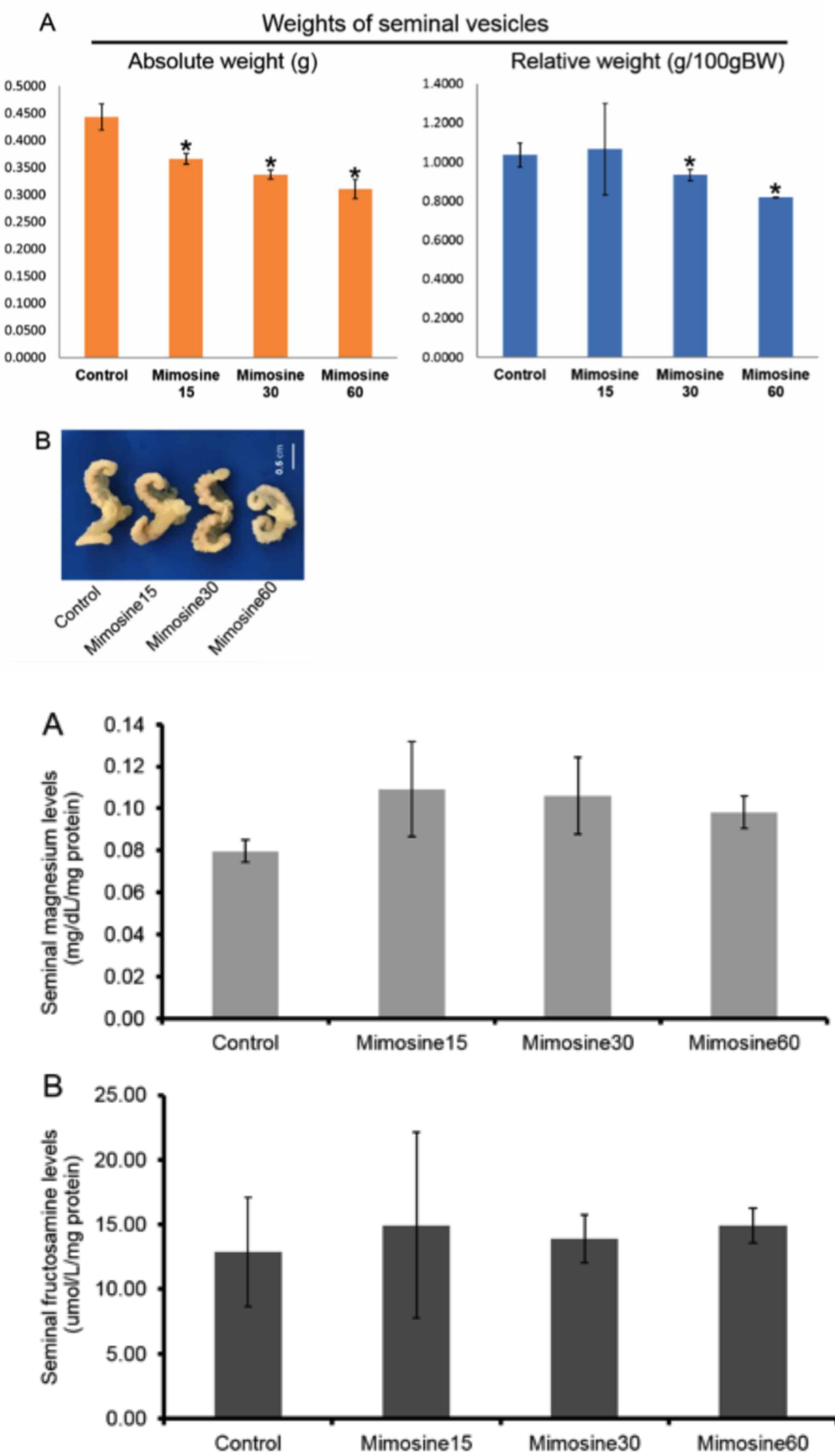

Fig. 1. Comparisons of seminal vesicles (SV) absolute and relative weights of control and mimosine-treated groups $(15,30$, and $60 \mathrm{mg} / \mathrm{KgBw}$, respectively) in 35 consecutive days (A). Representative SV morphology of control and mimosine groups (B). Each data point represented as means \pm S.D $(n=$ 8). * Significant difference $(\mathrm{p}<0.05)$ compared to the control
Fig. 2. Showing the levels of magnesium (A) and fructosamine (B) in seminal fluid of control and mimosine-treated mice $(15,30$, and $60 \mathrm{mg} / \mathrm{KgBw}$, respectively). Each data point represented as means \pm S.D. $(n=8)$. 
A

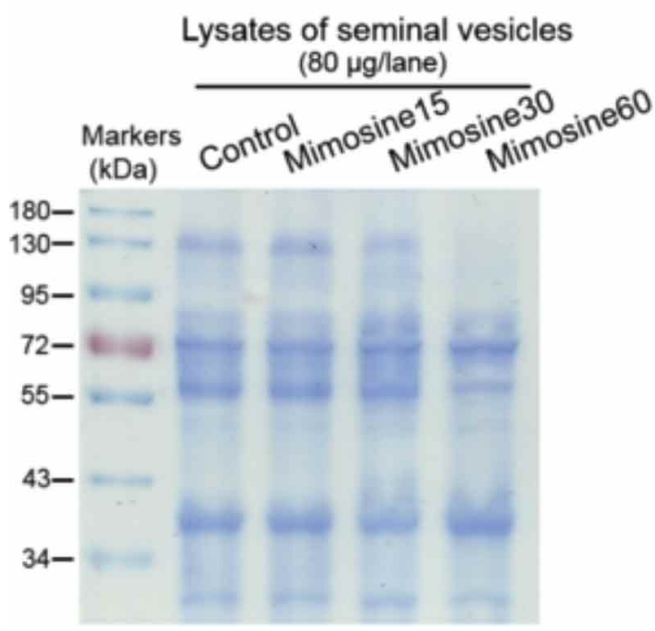

B

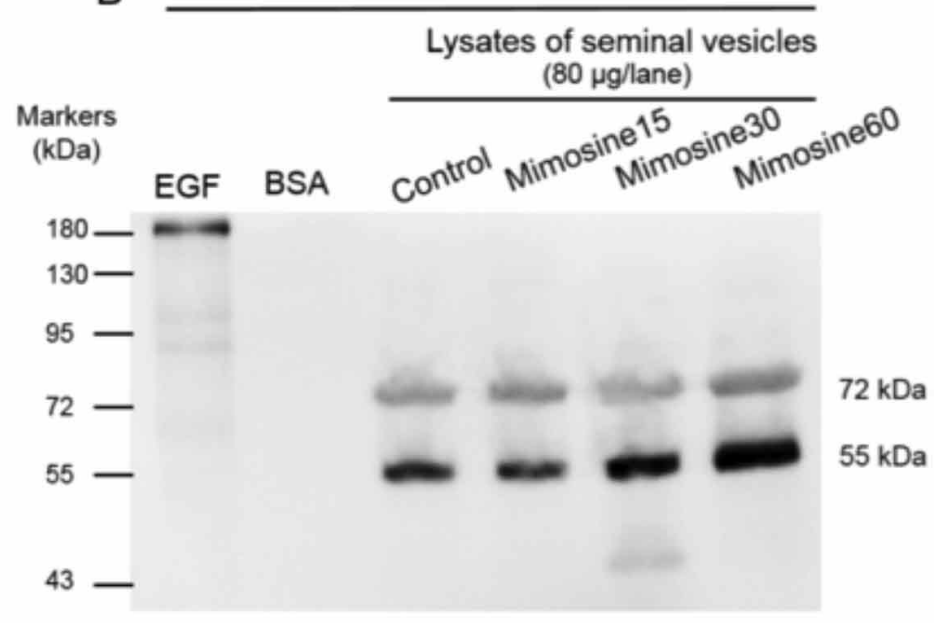

Fig. 3. Showing total protein profiles by SDS-PAGE (A) and expression of tyrosine phosphorylated (TyrPho) proteins detected by western blot in SV lysate (B) of control and mimosine-treated mice $(15,30$, and $60 \mathrm{mg} / \mathrm{KgBw}$, respectively) the epidermal growth factor (EGF) and bovine serum albumin (BSA) were used as positive and negative controls, respectively.

\section{DISCUSSION}

Mimosine (MiMo) has been proven to have activities against many cancers, cell divisions, cell proliferations and differentiations (Wang et al., 1995; Hughes \& Cook; Krude). Indeed, MiMo is a toxic substance in Leucaena leucocephala (LL) (Zayed et al., 2014; Burawat, 2017; Burawat et al., 2016, 2018). By using Thin Layer Chromatography (TLC) with method validation, Burawat et al. (2018) have demonstrated for the first time that MiMo levels in aqueous crude extract of LL shoot tips plus young leaves cultured in Northeastern, Thailand were approximately $17.35 \%$ dry crude extract. Particularly, both aqueous crude extract of LL shoot tips plus young leaves and purified MiMo have previously reported to have adverse effects on male reproductive mouse organs such as testis, epididymis, and seminal vesicle (Burawat et al., 2018; Kanla et al.). It has been shown that acute effect of MiMo treatment for 7 days could damage testicular tissue which may affect the sperm production resulted in significant decreasing of epididymal sperm concentration (Kanla et al.). Herein, our study has demonstrated the effect of MiMo treatment for 35 days on seminal vesicle for the first time. We have hypothesized that the levels of magnesium and fructosamine in MiMo treated mice might be decreased and associated with adverse reproductive parameters as previously reported (Burawat et al., 2018; Kanla et al.). Moreover, such levels have been reported to relate with male infertility (AbouShakra et al.; Tomaszewski et al.; Omu et al.; Wong et $a l$. .). Unfortunately, our results showed no difference in those levels among control and MiMo mice. In contrast, we found that MiMo at a dose of $60 \mathrm{mg} / \mathrm{KgBw}$ affected the decreased expression of a $130 \mathrm{kDa}$ protein in SV lysate as compared to the two lower groups. Moreover, the unknown TyrPho proteins of the 72 and $55 \mathrm{kDas}$ were investigated in seminal lysate for the first time but their expression were dose-dependently increased in purified MiMo groups $(15,30$, and $60 \mathrm{mg} / \mathrm{KgBw}$, respectively). Since seminal proteins including TyrPho proteins have been reported to be important in sperm capacitation and acrosome reaction before fertilization process (Aitken $e t$ al., 2007; Seshagiri et al.; Ickowicz et al.), the changes of protein expressions in MiMo treated SV may be involved in some sperm physiology in female tract. However, the characterization and functional roles of the 72 and $55 \mathrm{kDas}$ TyrPho proteins in MiMo treated SV need to be further elucidated. In conclusion, purified MiMo decreased the SV weights and increased the expressions of TyrPho proteins in seminal fluid. This finding may support the effects of mimosine in Leucaena leucocephala on adverse male reproductive parameters of domesticated animals.

\section{ACKNOWLEDGEMENTS}

This study was granted by Faculty of Medicine, Khon Kaen University, Thailand (Grant Number IN 61112) to AC and SI. We also thank Research Institute for Human High Performance and Health Promotion (HHP\&HP) for providing research assistantship to SI students. 
CHAICHUN, A.; BURAWAT, J.; ARUN, S.; TONGPAN, S.; KANLA, P.; SAWATPANICH, T. \& IAMSAARD, S. La mimosina aumenta la expresión de la proteína tirosina fosforilada en las vesículas seminales del ratón. Int. J. Morphol., 37(4):14631468, 2019.

RESUMEN: El efecto agudo de la mimosina purificada (MiMo) extraída de Leucaena leucocephala en la histopatología testicular se ha documentado con atrofia de vesícula seminal (VS). Debido a que la fosforilación de proteínas y las secreciones seminales tienen un papel importante en la fisiología de los espermatozoides, este estudio tuvo como objetivo estudiar la alteración de sustancias como la proteína tirosina fosforilada (TyrPho) en vesículas seminales tratadas con MiMo. Los ratones se dividieron en un grupo control y un grupo experimental y se trataron con MiMo purificado en 3 dosis de 15, 30 y $60 \mathrm{mg} /$ $\mathrm{KgBW}$, respectivamente, durante 35 días seguidos. La morfología y los pesos de VS se compararon entre los grupos. Fueron analizados los niveles de magnesio y fructosamina en el fluido VS. Los perfiles de las proteínas totales de VS se compararon utilizando SDS-PAGE. La expresión de la proteína TyrPho en las vesículas seminales se detectó mediante transferencia de Western blot. Los resultados recientes muestran la disminución del peso de las VS en ratones tratados con MiMo, en comparación con el grupo control. Sin embargo, en ninguna de las dosis se vieron afectados por mimosina purificada los niveles de magnesio y fructosamina en el líquido de las VS. La expresión de la proteína en VS de 130 y 55 kDas disminuyó notablemente en una dosis alta de MiMo. En la respuesta dependiente de la dosis, aumentaron las expresiones de 72 y $55 \mathrm{kDas}$ de las proteínas TyrPho en las VS. En conclusión, la mimosina purificada podría afectar el tamaño morfológico de las VS y la expresión de proteínas, especialmente las proteínas TyrPho.

PALABRAS CLAVE: Mimosina (MiMo); Vesícula seminal; Proteína tirosina fosforilada (TyrPho); Ratones.

\section{REFERENCES}

Abou-Shakra, F. R.; Ward, N. I. \& Everard, D. M. The role of trace elements in male infertility. Fertil. Steril., 52(2):307-10, 1989.

Adeneye, J. A. Mimosine content in various fractions of Leucaena leucocephala grown in western Nigeria. Anim. Feed Sci. Technol., 33(3-4):349-53, 1991.

Aitken, R. J.; Nixon, B.; Lin, M.; Koppers, A. J.; Lee, Y. H. \& Baker, M. A. Proteomic changes in mammalian spermatozoa during epididymal maturation. Asian J. Androl., 9(4):554-64, 2007.

Anderson, R. C.; Anderson, T. J.; Nisbet, D. J.; Kibbe, A. S.; Elrod, D. \& Wilkinson, G. Drought associated poisoning of cattle in South Texas by the high quality forage legume Leucaena leucocephala. Vet. Hum. Toxicol., 43(2):95-6, 2001.

Bottini-Luzardo, M.; Aguilar-Perez, C.; Centurion-Castro, F.; SolorioSanchez, F.; Ayala-Burgos, A.; Montes-Perez, R.; MuñozRodriguez, D. \& Ku-Vera, J. Ovarian activity and estrus behavior in early postpartum cows grazing Leucaena leucocephala in the tropics. Trop. Anim. Health Prod., 47(8):1481-6, 2015.

Burawat, J. Effects of Leucaena Leucocephala (Lamk.) De Wit Shoot Tips Plus Young Leaves Aqueous Extract Containing Mimosine on
Reproductive System of Adult Male Rats. Ph.D. Dissertation. Khon Kaen, Khon Kaen University, 2017.

Burawat, J.; Uabandit, N.; Arun, S.; Nualkaew, S. \& Iamsaard, S. Effects of Leucaena leucocephala (Lamk.) shoot tips plus young leaf extract containing mimosine on reproductive system of male rats. Int. J. Morphol., 36(3):1062-9, 2018.

Burawat, J.; Uabandit, N.; Sripanidkulchai, B.; Nualkaew, S. \& Iamsaard, S. Antioxidant capacity and acute testicular toxicity of Leucaena leucocephala aqueous shoot tips plus young leaves extracts. Int. J. Morphol., 34(2):514-21, 2016.

Camargo, M.; Intasqui, P. \& Bertolla, R. P. Understanding the seminal plasma proteome and its role in male fertility. Basic Clin. Androl., 28:6, 2018.

Chaichun, A.; Arun, S.; Burawat, J.; Kanla, P. \& Iamsaard, S. Localization and identification of tyrosine phosphorylated proteins in adult Sprague-Dawley rat testis. Int. J. Morphol., 35(4):1322-7, 2017.

Chung, L. C.; Tsui, K. H.; Feng, T. H.; Lee, S. L.; Chang, P. L. \& Juang, H. H. L-Mimosine blocks cell proliferation via upregulation of B-cell translocation gene 2 and N-myc downstream regulated gene 1 in prostate carcinoma cells. Am. J. Physiol. Cell Physiol., 302(4):C676-85, 2012.

Druart, X. \& de Graaf, S. Seminal plasma proteomes and sperm fertility. Anim. Reprod. Sci., 194:33-40, 2018.

Fallon, A. M. Effects of mimosine on Wolbachia in mosquito cells: cell cycle suppression reduces bacterial abundance. In Vitro Cell Dev. Biol. Anim., 51(9):958-63, 2015.

Hammond, A. C. Leucaena toxicosis and its control in ruminants. $J$. Anim. Sci., 73(5):1487-92, 1995.

Hughes, T. A. \& Cook, P. R. Mimosine arrests the cell cycle after cells enter S-phase. Exp. Cell Res., 222(2):275-80, 1996.

Ickowicz, D.; Finkelstein, M. \& Breitbart, H. Mechanism of sperm capacitation and the acrosome reaction: role of protein kinases. Asian. J. Androl., 14(6):816-21, 2012.

Kanla, P.; Burawat, J.; Arun, S.; Sawatpanich, T.; Chaichun, A. \& Iamsaard, S. Acute Effects of mimosine purified from Leucaena leucocephala on male reproductive system of adult mice. Int. J. Morphol., 36(2):507-12, 2018.

Krude, T. Mimosine arrests proliferating human cells before onset of DNA replication in a dose-dependent manner. Exp. Cell Res., 247(1):148-59, 1999.

Kubota, S.; Fukumoto, Y.; Ishibashi, K.; Soeda, S.; Kubota, S.; Yuki, R.; Nakayama, Y.; Aoyama, K.; Yamaguchi, N. \& Yamaguchi, N. Activation of the prereplication complex is blocked by mimosine through reactive oxygen species-activated ataxia telangiectasia mutated (ATM) protein without DNA damage. J. Biol. Chem., 289(9):5730-46, 2014.

Nguyen, B. C. \& Tawata, S. Mimosine dipeptide enantiomsers: improved inhibitors against melanogenesis and cyclooxygenase. Molecules, 20(8):14334-47, 2015.

Omu, A. E.; Al-Bader, A. A.; Dashti, H. \& Oriowo, M. A. Magnesium in human semen: possible role in premature ejaculation. Arch. Androl., 46(1):59-66, 2001.

Park. S. Y.; Im, J. S.; Park, S. R.; Kim, S. E.; Wang, H. J. \& Lee, J. K. Mimosine arrests the cell cycle prior to the onset of DNA replication by preventing the binding of human Ctf $4 /$ And-1 to chromatin via Hif-1a activation in HeLa cells. Cell Cycle, 11(4):761-6, 2012.

Sawatpanich, T.; Arun, S.; Tongpan, S.; Chaichun, A.; Sampannang, A.; Sukhorum, W.; Maneenin, C.; Burawat, J. \& Iamsaard, S. Localization and changes of tyrosine phosphorylated proteins and $\beta$ actin in epididymis of rats treated with valproic acid. Int. J. Morphol., 36(3):835-40, 2018.

Seshagiri, P. B.; Mariappa, D. \& Aladakatti, R. H. Tyrosine phosphorylated proteins in mammalian spermatozoa: molecular and functional aspects. Soc. Reprod. Fertil. Suppl., 63:313-25, 2007. 
Tawata, S. Effective Reduction and Extraction of Mimosine from Leucaena and the Potential for Its Use as a Lead Compound of Herbicides. In: Casida, J. E. (Ed.). Pesticide and Alternatives. Amsterdam, Elsevier Science Publishers, 1990. pp.541-54.

Tomaszewski, L.; Konarska, L.; Janczewski, Z.; Skarzynska, E.; Lebioda, K. \& Hryckiewicz, L. Fructosamine in human and bovine semen. Life Sci., 50(3):181-5, 1992.

Wang, Y.; Zhao, J.; Clapper, J.; Martin, L. D.; Du, C.; DeVore, E. R.; Harkins, K.; Dobbs, D. L. \& Benbow, R. M. Mimosine differentially inhibits DNA replication and cell cycle progression in somatic cells compared to embryonic cells of Xenopus laevis. Exp. Cell Res., 217(1):84-91, 1995.

Wayman, O.; Iwanaga, I. I. \& Hugh, W. I. Fetal resorption in swine caused by Leucaena leucocephala (Lam.) de Wit. in the diet. J. Anim. Sci., 30(4):583-8, 1970.

Wong, W. Y.; Flik, G.; Groenen, P. M.; Swinkels, D. W.; Thomas, C. M.; Copius-Peereboom, J. H.; Merkus, H. M. \& Steegers-Theunissen, R. $\mathrm{P}$. The impact of calcium, magnesium, zinc, and copper in blood and seminal plasma on semen parameters in men. Reprod. Toxicol., 15(2):131-6, 2001.

Zayed, M. Z.; Zaki, M. A.; Ahmad, F. B.; Ho, W. S. \& Pang, S. L. Comparison of mimosine content and nutritive values of Neolamarckia cadamba and Leucaena leucocephala with medicago sativa as forage quality index. Int. J. Sci. Technol. Res., 3(8):146-50, 2014.
Corresponding author:

Dr. Sitthichai lamsaard and Amnart Chaichun

Department of Anatomy

Faculty of Medicine

Khon Kaen University

123 Mitrapap Road

Amphoe Muang

Khon Kaen 40002

THAILAND

Email: sittia@kku.ac.th amnart.chai@gmail.com

Received: 18-02-2019

Accepted: 17-06-2019 